Available online on 15.11.2018 at http://ujpr.org
Universal Journal of Pharmaceutical Research
An International Peer Reviewed Journal
Open access to Pharmaceutical research

\title{
DEVELOPMENT AND CHARACTERIZATION OF DIRECT COMPRESSED MATRIX MINI TABLETS OF NAPROXEN SODIUM Oyeniran Taiwo Opeyemi ${ }^{1}\left(\mathbb{D}\right.$, Obanewa Opeyemi Adegbenro ${ }^{2}$ ${ }^{1}$ Department of Physiology, Faculty of Basic Medical Sciences, University of Ilorin, Nigeria. ${ }^{2}$ Department of Physiology University of Ibadan, Nigeria.
}

\section{ABSTRACT}

Objective: The present study was carried out to formulate and evaluate multiparticulate system containing mini-tablets of Naproxen sodium. Naproxen is a nonsteroidal anti-inflammatory drug (NSAIDs) with analgesic and antipyretic properties.

Methods: Pre-formulation studies showed good flow and compaction capacity, leading to the production of high quality minitablets. The drug-excipients compatibility studies were performed using FTIR techniques. Ten different matrix mini tablets were manufactured by direct compression using various polymers like HPMC K4M, PVP K30 in different ratio. The prepared mini tablets were subjected to pre and post compressional parameters and the values were within the prescribed limits.

Results: The in-vitro performance showed the desired biphasic behaviour. Drug release from matrix mini tablets was sustained over a period of 10 hours and release rate.

Conclusion: Study concludes that Naproxen sodium can be successfully released in a controlled manner by the use of developed matrix mini-tablets.

Keywords: HPMC K4M, in-vitro study, mini tablets, Naproxen sodium, NSAIDs, PVP K30.

Article Info: Received 4 September 2018; Revised 11 October; Accepted 6 November, Available online 15 November 2018

口다문 Cite this article- Opeyemi OT, Adegbenro OO. Development and characterization of direct compressed matrix mini tablets of naproxen sodium. Universal Journal of Pharmaceutical Research 2018; 3(5): 63-68.

DOI: https://doi.org/10.22270/ujpr.v3i5.205

Address for Correspondence:

Oyeniran Taiwo Opeyemi, Department of Physiology, Faculty of Basic Medical Sciences, University of Ilorin, Nigeria. E-mail: tinwoye2011@gmail.com

\section{INTRODUCTION}

Oral tablets are the most widely used dosage form due to compactness, ease in manufacturing and convenience in terms of self-administration ${ }^{1}$. Matrix technologies are very popular among the oral controlled drug delivery technologies due to their simplicity, ease in manufacturing, high level of reproducibility, stability of the raw materials and dosage form and ease of scale-up and process validation $^{2,3,4,}$. Matrix tablets are the "oral solid dosage forms in which the drug or active ingredient is homogeneously dispersed throughout the hydrophilic or hydrophobic matrices which serves as release rate retardants. Mini tablets are yet another category of solid oral formulation that offers analogous therapeutic benefits. Mini tablets have diameter typically equal to or smaller than $3.0 \mathrm{~mm}^{\mathbf{5 , 6}}$. Mini tablets can be prepared very easily by the means of direct compression method. These mini tablets can be filled into hard gelatine capsules, can be administered with a dose dispenser for individual dosing or can be compressed into larger tablets $^{7,8}$. Matrix mini tablets as multiparticulate dosage forms score more advantages like uniformity of drug release, less tendency of dose dumping, greater patience compliance, improved mechanical strength, more dose loading capacity, and uniformity of size and shape?. Furthermore mini tablets can maintain their structure and shape in a more reproducible way than pellets or granules ${ }^{10}$

The significant anatomical differences of the buccal cavity within paediatric and adult patients mean that children, particularly those under 5 years of age, encounter swallowing difficulties. Mini tablets are a potentially suitable dosage form for paediatric drug delivery ${ }^{11,12}$. Naproxen is a nonsteroidal antiinflammatory drug (NSAID) with analgesic and antipyretic properties that relieves pain, fever, swelling, and stiffness. It is commonly used as sodium salt ${ }^{13}$. Naproxen itself is rapidly and completely absorbed from the GI tract with an in-vivo bioavailability of $95 \%$. Naproxen is extensively metabolized to 6-0desmethyl naproxen and both parent and metabolites do not induce metabolizing enzymes ${ }^{14}$. The elimination half-life of Naproxen is approximately 15 hours. Most of the drug is excreted in the urine and a small amount $(<5 \%)$ of the drug is excreted in the faeces. Since 
Naproxen is extensively bound to plasma albumin, so it may be more efficient to deliver this drug in its sustained-release dosage form ${ }^{15}$.

The aim of present investigation is to design development and characterize the controlled release matrix mini tablets of Naproxen sodium with varying proportions of selective polymers. To release the drug for a prolong period of time within the GIT, thus to improve the patient compliance. By the means of controlled drug delivery systems danger of dose dumping and alteration in drug release profile can be avoided.

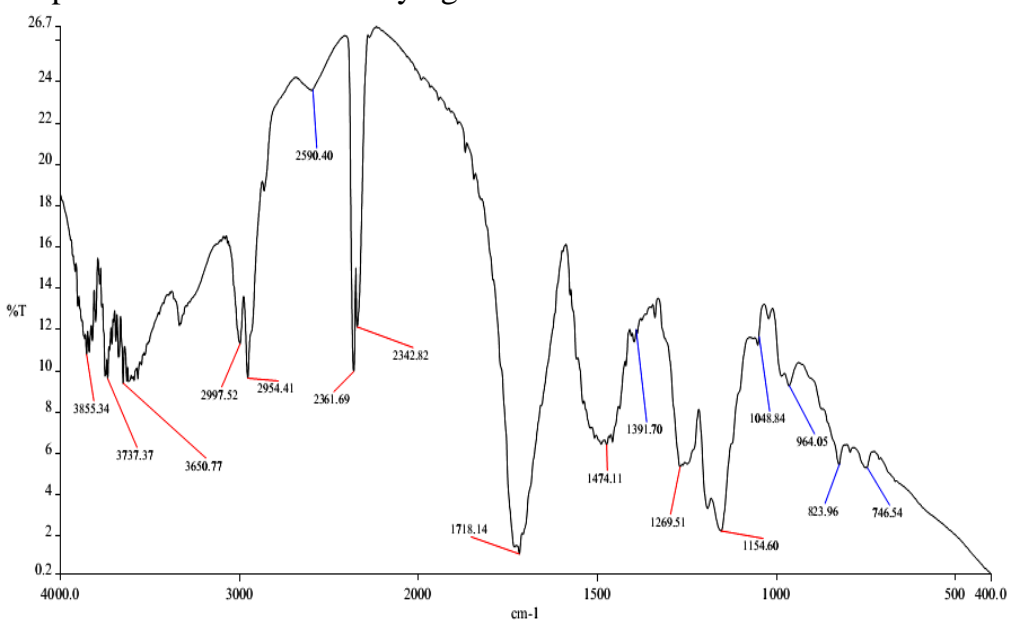

Figure 1: FTIR spectrum of Naproxen sodium.

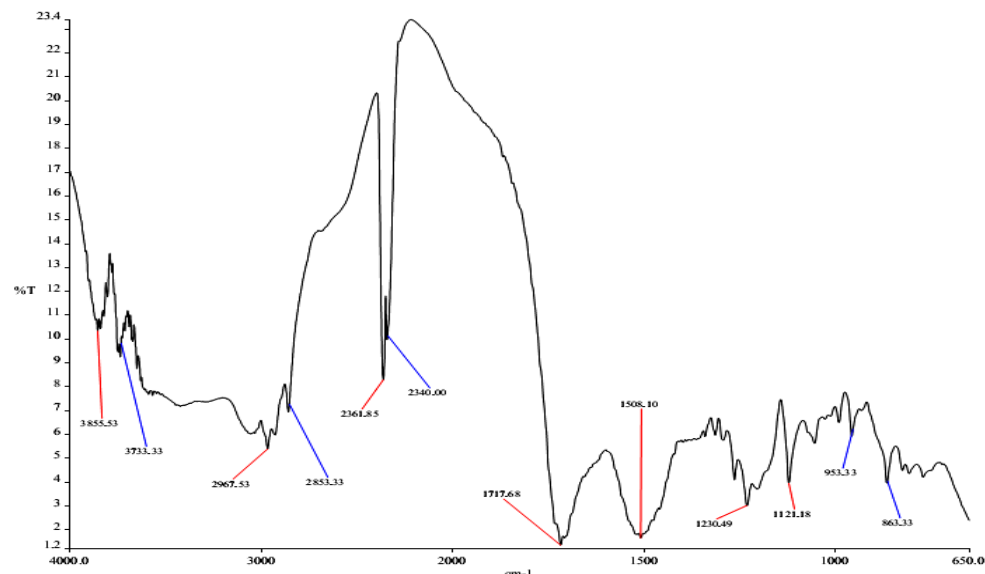

Figure 2: FTIR spectrum of mixture of Naproxen sodium, HPMC K4M and PVP K30.

\section{MATERIALS AND METHODS}

Naproxen sodium was obtained from Adpharm Pharmaceuticals Limited, Lagos State, Nigeria. PVP K30 and Magnesium stearate were obtained from Afrab-Chem Limited, Lagos State, Nigeria. Aerosil was obtained from Agary Pharmaceutical Limited, Lagos State, Nigeria. Sodium lauryl Sulphate and Avicel were obtained from Biopharma Nigeria Limited, Lagos State, Nigeria. All other ingredients, chemicals and solvents used were of analytical grade.

\section{Preformulation studies}

Fourier Transform Infrared (FTIR) spectral analysis

The compatibility for pure drug Naproxen, polymers and their physical mixtures used in this experimental procedure was evaluated by recording of spectra using FT-IR Spectrophotometer (Perkin Elmer, spectrum100, Japan). The spectra were recorded by taking $5 \%$ of sample in potassium bromide $(\mathrm{KBr})$ and after this mixture was grounded into a fine powder it was compressed into $\mathrm{KBr}$ pellets at 4000 Psi compaction pressure for a period of $2 \mathrm{~min}^{16}$.

\section{Angle of repose}

The fixed funnel and free standing cone methods employ a funnel that is secured with its tip at a given height, $\mathrm{h}$, which was kept $2 \mathrm{~cm}$ above graph paper that is placed on a flat horizontal surface ${ }^{17}$. With $r$ being the radius, of base of conical pile, angle of repose can be determined by following equation:

$$
\tan \theta=\frac{\mathrm{h}}{\mathrm{r}}
$$

Where, $\theta$ is the angle of repose, $\mathrm{h}$ is height of pile; $\mathrm{r}$ is radius of base of the pile.

\section{Bulk density and tapped density}

Both loose bulk density and tapped bulk density were determined. A quantity of $2 \mathrm{gm}$ of granules from each formula, previously light Shaken for the break of any agglomerates formed, was introduced into the $10 \mathrm{ml}$ of measuring cylinder. After the initial volume was observed, the cylinder was allowed to fall down its own weight from the hard surface from a height of $2.5 \mathrm{~cm}$ at $2 \mathrm{sec}$ intervals ${ }^{18}$. The tapping was continued until no further change in the volume was noted LBD and TBD were calculated using the following formulas: 


$$
\begin{aligned}
& \text { Bulk Density }=\frac{\text { Weight of sample }(\mathrm{gm})}{\text { Volume occupied by sample }(\mathrm{ml})} \\
& \text { Tapped Density }=\frac{\text { Weight of powdered blend }(\mathrm{gm})}{\text { Tapped volume of the packing }(\mathrm{ml})}
\end{aligned}
$$

\section{Compressibility index}

The compressibility index of the granules was determined by Carr's Compressibility index.

Compressibility Index $=\frac{\text { Tapped Density }- \text { Bulk Density }}{\text { Tapped Density }} X 100$

\section{Hausner's ratio}

Hausner's ratio can be determined by the following equation,

$$
\text { Hausner Ratio }=\frac{\text { Tapped Density }}{\text { Bulk Density }}
$$

\section{Preparation of matrix mini tablet}

Naproxen sodium matrix mini-tablets were prepared by direct compression technique ${ }^{19}$. Tablet ingredients were accurately weighed as mentioned in the Table 1. All ingredients were then passed through \#20 mesh sieve. After screening, the powdered ingredients were blended in a large size poly bag by tumbling action. Finally, magnesium stearate was added and again mixed for 5 minutes so that particle surface was coated by lubricant evenly. The blend was then compressed into mini tablets weighing about $100 \mathrm{mg}$ using $2.8 \mathrm{~mm}$ shallow biconcave punches in rotary tablet punching machine to a hardness of $5-6 \mathrm{Kg} / \mathrm{cm}^{2}$. The prepared mini tablets were used for further evaluation studies.

Table 1: Composition of Naproxen sodium matrix mini-tablets formulations (mg/mini tablet).

\begin{tabular}{|c|c|c|c|c|c|}
\hline Batch & $\begin{array}{c}\text { Angle of repose }\left(^{\circ}\right) \\
\text { mean } \pm S D, n=3\end{array}$ & $\begin{array}{c}\text { Bulk density } \\
(\mathrm{g} / \mathrm{cc}) \\
\text { mean } \pm \text { SD, } \mathrm{n}=3\end{array}$ & $\begin{array}{l}\text { Tapped density } \\
(\text { g/cc) } \\
\text { mean } \pm \text { SD, } n=3\end{array}$ & $\begin{array}{c}\text { Carr's index } \\
\text { mean } \pm \mathrm{SD}, \mathrm{n}=3\end{array}$ & $\begin{array}{c}\text { Hausner's ratio } \\
\text { mean } \pm \text { SD, } \\
n=3\end{array}$ \\
\hline MT1 & $24.59 \pm 0.09$ & $0.521 \pm 0.32$ & $0.581 \pm 0.09$ & $10.32 \pm 0.22$ & $1.11 \pm 0.08$ \\
\hline MT2 & $22.31 \pm 0.35$ & $0.558 \pm 0.09$ & $0.618 \pm 0.14$ & $9.70 \pm 0.45$ & $1.10 \pm 0.11$ \\
\hline MT3 & $23.48 \pm 0.44$ & $0.547 \pm 0.15$ & $0.607 \pm 0.23$ & $9.88 \pm 0.10$ & $1.10 \pm 0.24$ \\
\hline MT4 & $23.75 \pm 0.37$ & $0.568 \pm 0.38$ & $0.628 \pm 0.31$ & $9.55 \pm 0.25$ & $1.10 \pm 0.31$ \\
\hline MT5 & $22.67 \pm 0.59$ & $0.564 \pm 0.49$ & $0.624 \pm 0.08$ & $9.93 \pm 0.47$ & $1.10 \pm 0.52$ \\
\hline MT6 & $21.88 \pm 0.82$ & $0.572 \pm 0.31$ & $0.632 \pm 0.25$ & $9.49 \pm 0.94$ & $1.10 \pm 0.16$ \\
\hline MT7 & $22.69 \pm 0.08$ & $0.548 \pm 0.61$ & $0.608 \pm 0.09$ & $9.86 \pm 0.62$ & $1.10 \pm 0.26$ \\
\hline MT8 & $22.42 \pm 0.07$ & $0.559 \pm 0.25$ & $0.619 \pm 0.18$ & $9.69 \pm 0.23$ & $1.10 \pm 0.08$ \\
\hline MT9 & $24.38 \pm 0.49$ & $0.572 \pm 0.16$ & $0.632 \pm 0.06$ & $9.49 \pm 0.17$ & $1.10 \pm 0.41$ \\
\hline MT10 & $22.58 \pm 0.39$ & $0.545 \pm 0.27$ & $0.605 \pm 0.09$ & $11.00 \pm 0.20$ & $1.11 \pm 0.09$ \\
\hline
\end{tabular}

\begin{tabular}{cccccccc}
\hline Batch & $\begin{array}{c}\text { Drug } \\
(\mathbf{m g})\end{array}$ & $\begin{array}{c}\text { HPMC } \\
\text { K4M } \\
(\mathbf{m g})\end{array}$ & $\begin{array}{c}\text { PVP K30 } \\
(\mathbf{m g})\end{array}$ & $\begin{array}{c}\text { Magnesium } \\
\text { stearate } \\
(\mathbf{m g})\end{array}$ & $\begin{array}{c}\text { Aerosil } \\
(\mathbf{m g})\end{array}$ & $\begin{array}{c}\text { Sodium lauryl } \\
\text { Sulphate }(\mathbf{m g})\end{array}$ & $\begin{array}{c}\text { Avicel } \\
(\mathbf{m g})\end{array}$ \\
\hline MT1 & 18 & 1.20 & 1 & 0.25 & 0.25 & 0.20 & 10.10 \\
MT2 & 18 & 1.26 & 1 & 0.25 & 0.25 & 0.20 & 11.24 \\
MT3 & 18 & 2.42 & 1 & 0.25 & 0.25 & 0.20 & 12.58 \\
MT4 & 18 & 2.68 & 1 & 0.25 & 0.25 & 0.20 & 14.32 \\
MT5 & 18 & 2.70 & 1 & 0.25 & 0.25 & 0.20 & 15.60 \\
MT6 & 18 & 3.10 & 1 & 0.25 & 0.25 & 0.20 & 16.20 \\
MT7 & 18 & 3.42 & 1 & 0.25 & 0.25 & 0.20 & 15.88 \\
MT8 & 18 & 3.52 & 1 & 0.25 & 0.25 & 0.20 & 16.78 \\
MT9 & 18 & 3.68 & 1 & 0.25 & 0.25 & 0.20 & 15.62 \\
MT10 & 18 & 3.79 & 1 & 0.25 & 0.25 & 0.20 & 15.51 \\
\hline
\end{tabular}

Table 2: Results of physical evaluation of pre-compression blend.

\section{Evaluation of mini tablets}

\section{Tablet thickness}

The thickness of 20 Naproxen sodium matrix minitablets was determined using a Vernier calliper and the mean of these readings was taken as the mean tablet thickness.

\section{Tablet weight uniformity}

Ten Naproxen sodium matrix mini-tablets were weighed individually on electric balance from which the mean was calculated and the percentage deviations determined.

\section{Friability}

A friability test was conducted on the tablets using an Veego friabilator. Twenty Naproxen sodium matrix mini-tablets were selected from each batch and any loose dust was removed with the help of a soft brush. The tablets were initially weighed $\left(\mathrm{W}_{\mathrm{i}}\right)$ and transferred into friabilator. The drum was rotated at $25 \mathrm{rpm}$ for 4 minutes after which the tablets were removed. Any loose dust was removed from the tablets as before and the tablets were weighed again $\left(\mathrm{W}_{\mathrm{f}}\right)$. The friability of tablets less than $1 \%$ was considered acceptable ${ }^{20}$. The percentage friability was then calculated by,

$$
\% F=\frac{W i-W f}{W i} X 100
$$

\section{Hardness}

The Naproxen sodium matrix mini-tablets to be tested were held between a fixed and a moving jaw of hardness test apparatus (Monsanto) and reading of the indicator is adjusted to zero. The screw knob was moved forward until the tablet breaks and the force required breaking the tablet was noted ${ }^{21}$.

\section{Drug content}

The drug content in each Naproxen sodium matrix mini-tablet was determined by triturating 20 tablets and powder equivalent to average weight was added in $100 \mathrm{ml} \mathrm{pH} 1.2 \mathrm{HCl}, 7.4$ and $6.8 \mathrm{pH}$ phosphate buffer, followed by stirring. The solution was filtered through a $0.45 \mu$ membrane filter, diluted suitably and the 
absorbance of resultant solution was measured spectrophotometrically at $331 \mathrm{~nm}$ using $\mathrm{pH} 1.2 \mathrm{HCL}$ and $\mathrm{pH} 7.4,6.8$ phosphate buffers as blank ${ }^{22}$.

In-vitro drug release study

In vitro release studies of Naproxen sodium matrix mini tablets were carried out using a modified USP XXIII dissolution test apparatus. The dissolution study was conducted for all the formulations using paddle method. The dissolution test was performed using $900 \mathrm{ml}$ of buffer $\mathrm{pH} 7.4$ at a speed of $50 \mathrm{rpm}$ and the temperature of $37^{\circ} \mathrm{C}$ was used in each test samples of dissolution $(5 \mathrm{ml})$ were withdrawn and absorbance was measured at $331 \mathrm{~nm}$ using analysis by UV spectroscopy. The dissolution data was fitted to models such as zero-order, first-order, Higuchi and Peppa's Korsemeyer equations ${ }^{23}$.

Table 3: Results of physicochemical parameters of all formulations.

\begin{tabular}{lccccc}
\hline Batch & $\begin{array}{c}\text { Thickness } \\
(\mathbf{m m}),\end{array}$ & $\begin{array}{c}\text { Hardness }(\mathbf{K g}) \\
(\mathbf{m e a n} \pm \mathbf{S D}), \mathbf{n = 6}\end{array}$ & $\begin{array}{c}\text { \% Friability } \\
(\mathbf{m e a n} \pm \mathbf{S D}), \\
\mathbf{n = 2 0}\end{array}$ & $\begin{array}{c}\text { Weight variation, } \\
(\mathbf{m g})\end{array}$ & $\begin{array}{c}\text { \% Drug content } \\
(\mathbf{m e a n} \pm \mathbf{S D}), \mathbf{n}=\mathbf{2 0}\end{array}$ \\
\hline MT1 & $3.7 \pm 0.08$ & $4.9 \pm 0.14$ & $0.45 \pm 0.09$ & $305.55 \pm 0.09$ & $98.46 \pm 0.09$ \\
MT2 & $4.2 \pm 0.15$ & $4.6 \pm 0.09$ & $0.38 \pm 0.35$ & $303.38 \pm 0.06$ & $99.12 \pm 0.09$ \\
MT3 & $3.8 \pm 0.38$ & $4.8 \pm 0.06$ & $0.43 \pm 0.27$ & $300.27 \pm 0.11$ & $99.41 \pm 0.27$ \\
MT4 & $3.9 \pm 0.05$ & $4.9 \pm 0.05$ & $0.39 \pm 0.49$ & $298.34 \pm 0.43$ & $99.12 \pm 0.09$ \\
MT5 & $4.2 \pm 0.62$ & $5.0 \pm 0.14$ & $0.35 \pm 0.51$ & $299.47 \pm 0.51$ & $98.49 \pm 0.09$ \\
MT6 & $4.3 \pm 0.41$ & $5.1 \pm 0.26$ & $0.40 \pm 0.08$ & $304.38 \pm 0.60$ & $97.83 \pm 0.09$ \\
MT7 & $4.0 \pm 0.53$ & $4.6 \pm 0.42$ & $0.42 \pm 0.26$ & $303.53 \pm 0.23$ & $98.56 \pm 0.17$ \\
MT8 & $4.4 \pm 0.08$ & $5.0 \pm 0.38$ & $0.38 \pm 0.07$ & $307.58 \pm 0.58$ & $99.43 \pm 0.13$ \\
MT9 & $3.8 \pm 0.12$ & $4.9 \pm 0.08$ & $0.45 \pm 0.11$ & $303.48 \pm 0.93$ & $97.56 \pm 0.05$ \\
MT10 & $4.1 \pm 0.36$ & $5.3 \pm 0.03$ & $0.41 \pm 0.16$ & $305.36 \pm 0.41$ & $98.86 \pm 0.17$ \\
\hline
\end{tabular}

Table 4: Drug release kinetics of different Naproxen sodium matrix mini-tablets.

\begin{tabular}{|c|c|c|c|c|c|}
\hline \multirow[t]{2}{*}{ Batch } & \multirow{2}{*}{$\begin{array}{c}\text { Zero order } \\
\left(\mathbf{R}^{\mathbf{2}}\right)\end{array}$} & \multirow{2}{*}{$\begin{array}{c}\text { First order } \\
\left(\mathbf{R}^{2}\right)\end{array}$} & \multirow{2}{*}{$\begin{array}{c}\text { Higuchi's } \\
\left(\mathbf{R}^{2}\right)\end{array}$} & \multicolumn{2}{|c|}{ Korsemeyer-Peppa's } \\
\hline & & & & $\mathbf{R}^{2}$ & $\mathbf{n}$ \\
\hline MT1 & 0.8815 & 0.8952 & 0.7685 & 0.9356 & 0.6842 \\
\hline MT2 & 0.9239 & 0.9039 & 0.8378 & 0.9238 & 0.6937 \\
\hline MT3 & 0.8641 & 0.8478 & 0.7153 & 0.9129 & 0.6689 \\
\hline MT4 & 0.9049 & 0.8816 & 0.7579 & 0.9348 & 0.6594 \\
\hline MT5 & 0.8932 & 0.9273 & 0.7368 & 0.9068 & 0.6736 \\
\hline MT6 & 0.9278 & 0.8792 & 0.7932 & 0.9241 & 0.6542 \\
\hline MT7 & 0.8664 & 0.8785 & 0.8649 & 0.8937 & 0.6713 \\
\hline MT8 & 0.9093 & 0.9129 & 0.7583 & 0.9537 & 0.6849 \\
\hline MT9 & 0.8881 & 0.9063 & 0.8594 & 0.9248 & 0.6932 \\
\hline MT10 & 0.9134 & 0.9171 & 0.8951 & 0.8639 & 0.6852 \\
\hline
\end{tabular}

\section{RESULTS AND DISCUSSION}

Granules of all the ten formulations were subjected for various pre-compressional evaluations such as angle of repose, bulk and tapped density, compressibility index and Hausner's ratio. Results of all the precompressional parameters performed on granules for formulations shown in Table 2. The angle of repose was found to be in the range of 21.88 to $24.59^{\circ}$. It indicates that granules have a good flow property. The bulk density and tapped density was found to be in the range of $0.521 \pm 0.32$ to $0.572 \pm 0.31 \mathrm{~g} / \mathrm{cm}^{3}$ and $0.581 \pm 0.09$ to $0.633 \pm 0.25 \mathrm{~g} / \mathrm{cm}^{3}$ respectively. The compressibility and Hausner ratio was found to be $9.47 \pm 0.17$ to $11.00 \pm 0.20$ and $1.10 \pm 0.16$ to $1.11 \pm 0.09$ indicating good flow character of the granules (Table 2). All the results are within the prescribed limits. The hardness of the tablets for all the formulations was in the range of $5-7 \mathrm{Kg} / \mathrm{cm}^{2}$. The uniformity weight of twenty tablets of all the formulations was within 5\% deviation. Another measure of a tablet's strength is friability. Conventional compressed tablets that lose less than $1 \%$ of their weight are generally considered acceptable. Results of friability test were also has been found within limit. The friability of all the formulation was less than $1 \%$. Drug content of all the formulations were found to be in the range of 96 to $99 \%$ (Table 3).
All the results are within the prescribed limits. The FT-IR studies showed that $\mathrm{C}-\mathrm{H}$ stretching, C-O stretching, C-H bending, O-H deformation, C-H out of plane bending of pure Naproxen sodium and with PVP $\mathrm{K} 30$ and HPMC K4M were almost in the same region of wave number ranging from $4000 \mathrm{~cm}^{-1}$ to $400 \mathrm{~cm}^{-1}$. It showed that there was no significant interaction between the drug and polymer and they are compatible with each other.

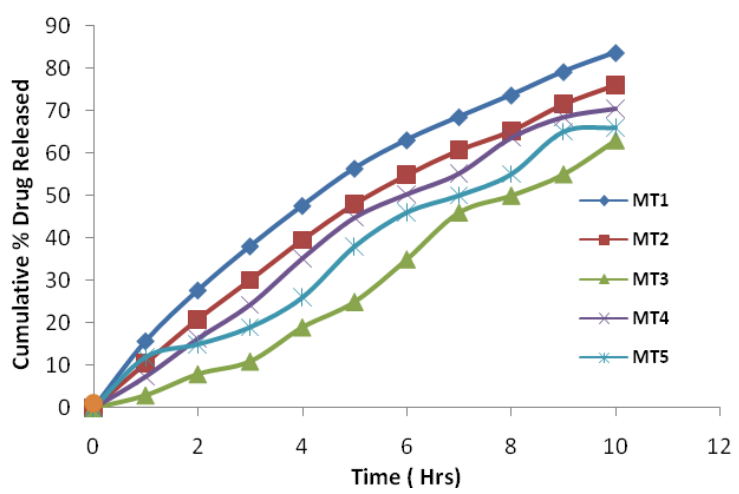

Figure 3: In-vitro drug release profile of Naproxen sodium matrix mini-tablets of batch MT1 to MT5.

The results of the in-vitro release study for all the 10 formulations are shown in Figure 3 and Figure 4. At 
the end of $10 \mathrm{hrs}$ the maximum cumulative percentage drug release $84.725 \%$ was shown by the batch MT1 and minimum 55.42 was shown by batch MT8. An increase in the compression force increases the hardness and the apparent density of the tablet, thereby reducing the matrix porosity in the tablet. As the compression force increases, release rate decreases ${ }^{6}$. The drug release was found to be faster at lower compression force than at higher ones because of the relatively larger matrix porosity of the tablet, which allowed greater penetration of dissolution fluid into the matrix, thus enhancing polymer disentanglement and drug dissolution ${ }^{11}$. The controlled drug release may also be due to increased proportion of polymer ${ }^{15}$.

The release rate kinetic data for all formulations is shown in Table 5. When the data were plotted according to zero order, the formulations showed a high linearity with regression coefficient values $\left(\mathrm{R}^{2}\right)$ between $0.8664-0.9278$. It showed that the drug release follows zero order.

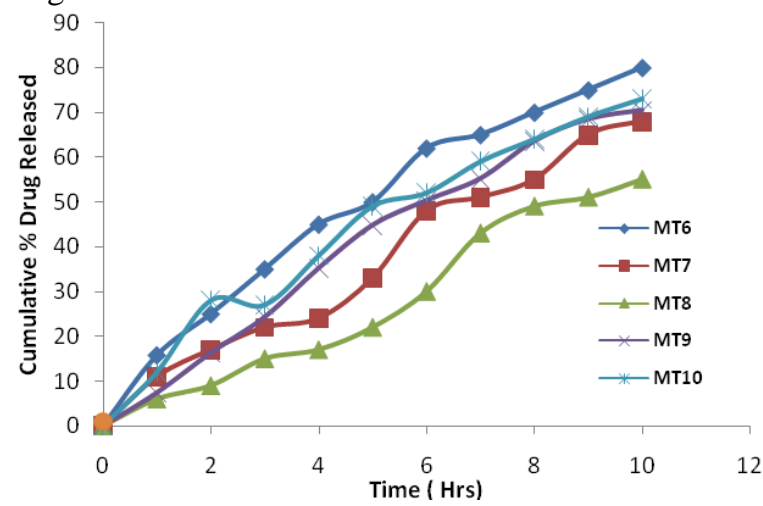

Figure 4: In-vitro drug release profile of Naproxen sodium matrix mini-tablets of batch MT6 to MT10.

When the data were plotted according to first order, the formulations showed regression coefficient values $\left(\mathrm{R}^{2}\right)$ between 0.8478-0.9173. Diffusion is related to transport of drug from the matrix tablets into the dissolution medium depends upon the concentration. This is explained by Higuchi's equation. When the data were plotted according to Higuchi's equations, the regression co-efficient values $\left(\mathrm{R}^{2}\right)$ were between 0.7153-0.8951. By using Korsmeyer-Peppas model, the mechanism of drug release was determined. If $n=<$ 0.45 , it is Fickian diffusion and if $n=0.45-0.89$, it is non Fickian diffusion transport ${ }^{12}$. The results of all the formulations showed that the $\mathrm{n}$ values are between $0.6542-0.6937$. It proved that all formulations followed non-Fickian transport mechanism19 both diffusion and erosion"

\section{CONCLUSION}

The study was undertaken with the aim to formulation and evaluation of Naproxen sodium sustained-release matrix tablets using various concentrations of polymers. It was concluded that there was no interaction between the drug and polymer compatibility, which is analyzed by FTIR. Ten different formulations of matrix mini tablets were prepared successfully by direct compression technique. The physicochemical evaluation studies like thickness, hardness, drug content, weight variation and friability were performed. From the obtained results, it is concluded that the formulation of sustained release tablet of Naproxen sodium of batch MT1 is considered as ideal or optimized. Therefore the study proves that Naproxen sodium can be successfully released in a controlled manner by the use of developed matrix mini-tablets.

\section{AUTHOR'S CONTRIBUTION}

The manuscript was carried out, written, and approved in collaboration with all authors.

\section{ACKNOWLEDGEMENTS}

The authors extend their thanks and appreciation to the University of Ilorin, Nigeria to provide necessary facilities for this work.

\section{CONFLICT OF INTEREST}

No conflict of interest is associated with this work.

\section{REFERENCES}

1. Mirelabodea Ioan tomuţă, Sorin L. Identification of critical formulation variables for obtaining metoprolol tartrate mini-tablets. Farmacia 2010; 58:719-727.

2. Zhang YE, Tchao R, Schwartz JB. Effect of processing methods and heat treatment on the formation of wax matrix tablets for sustained drug release. Pharm Dev Technol 201; 6:131-144. https://doi.org/10.1081/PDT-100000736

3. Alyahawi A, Abdulmajed A. Quality control assessment of different brands of ciprofloxacin $500 \mathrm{mg}$ tablets in Yemen. Universal J Pharm Res 2018; 3(4): 31-36. https://doi.org/10.22270/ujpr.v3i4.180

4. Hamdani J, Moës AJ, Amighi K. Development and evaluation of prolonged release pellets obtained by the melt pelletization process. Int J Pharm 2002; 245:167-177. https://doi.org/10.1016/s0378-5173(02)00348-4

5. Abdulmajed A, Alyahawi A. Quality assessment of different brands of paracetamol tablets in Yemeni market Universal J Pharm Res. 2018; 3(4): 42-47. https://doi.org/10.22270/ujpr.v3i4.182

6. Prajapati $\mathrm{P}$, et al. Evaluation of controlled release ophthalmic minitablets prepared by direct compression. Int J Pharma Research Dev 2010; 2(9):205-216.

7. Singh S, Virmani T, Virmani R, Kumar P, Mahlawat G. Fast dissolving drug delivery systems: formulation, preparation techniques and evaluation. Universal $\mathrm{J}$ Pharm Res 2018; 3(4): 60-69. https://doi.org/10.22270/ujpr.v3i4.185

8. Hamza Yel-S, Aburahma MH. Innovation of novel sustained release compression-coated tablets for lornoxicam: formulation and in vitro investigations. Drug Dev Ind Pharm 2010; 36:337-349. https://doi.org/10.1080/03639040903170768

9. Chauhan V, Kumar K, Teotia D. Fast dissolving tablets: a promising approach for drug delivery. Universal $\mathrm{J}$ Pharm Res. 2017; 2(4): 58-64. https://doi.org/10.4103/2231-4040.90877

10. Ishida M, Abe K, Hashizume M and Kawamura M. A novel approach to sustained pseudoephedrine release: Differentially coated mini-tablets in HPMC capsules. Int $\mathbf{J}$ Pharm 2008; 359: 46-52. https://doi.org/10.1016/j.ijpharm.2008.03.034

11. Saddam C Shaikh, Dnyaneshwar S, Dipak V Bhusari, Jain S, Pooja P Kochar, Vikram N Sanchati. Formulation and evaluation of Ibuprofen gastro-retentive floating tablets. Universal J Pharm Res 2018; 3(4): 20-25.

https://doi.org/10.22270/ujpr.v3i4.178 
12. Zhang YE, Schwartz JB. Effect of diluents on tablet integrity and controlled drug release. Drug Dev Ind Pharm 2000; 26:761-765. https://doi.org/10.1081/ddc-100101295

13. Duggan KC, Walters MJ, Musee J, Harp JM, Kiefer JR, Oates JA, Marnett LJ. Molecular basis for cyclooxygenase inhibition by the non-steroidal anti-inflammatory drug naproxen. The J Biol Chem 2010; 285 (45): 34950-9. https://doi.org/10.1074/jbc.M110.162982

14. Hinz B, Cheremina O, Besz D, Zlotnick S, Brune K. Impact of naproxen sodium at over-the-counter doses on cyclooxygenase isoforms in human volunteers. International J Clin Pharm Therap. 2008; 46 (4): 180-6.

15. Harrington PJ, Lodewijk E. Twenty Years of Naproxen Technology. Org Process Res Dev 1997; 1 (1): 72-76. https://doi.org/10.1021/op960009e

16. Igwe J. Chibueze, Emenike IV, Oduola AR. Formulation and evaluation of Finasteride sustained-release matrix tablets using different rate controlling polymers. Universal $\mathbf{J}$ Pharm Res 2016; 1(2): 25-31.

https://doi.org/10.22270/ujpr.v1i2.R3

17. Lopes CM, Loboa JSM, Pinto JF, Costa P. Compressed mini-tablets as a biphasic delivery system. Int J Pharm 2006; 323: 93-100.

https://doi.org/10.1016/j.ijpharm.2006.05.063

18. Nweje-Anyalowu Paul C, Anyalogbu Ernest AA, White Alalibo Jim. Design and evaluation of chronotherapeutic pulsatile drug delivery system of Cilnidipine. Universal $\mathrm{J}$ Pharm Res 2017; 2(5): 18-22.

https://doi.org/10.4161/biom.1.1.17717

19. Carla Lopes M, José Manuel, Sousa Lobo, Paulo Costa, João Pinto F, Directly compressed mini matrix tablets containing ibuprofen: preparation and evaluation of sustained release. Drug Dev Ind Pharm 2006; 32(1): 95106. https://doi.org/10.1080/03639040500388482

20. Mastoi SM, Ali A, Aslam H, Niaz K. Comparision of antidyslipiemic potential of 80 milligrams of Fenofibrated with 8 grams of Nigella sativa seeds daily. Universal $\mathbf{J}$ Pharm Res 2017; 2(6): 50-52. https://doi.org/10.22270/ujpr.v2i6.R9

21. Sujja-Areevath J, Munday DL, Cox PJ, Khan KA. Release characteristics of diclofenac sodium from encapsulated natural gum mini-matrix formulations. Int J Pharm 2005; 139:53-62. https://doi.org/10.1016/0378-5173(96)04573-5

22. Hadi, Mohd Abdul, Raghavendra Rao, Srinivasa Rao. Matrix-mini-tablets of lornoxicam for targeting early morning peak symptoms of rheumatoid arthritis. Iran J Bas Med Sci 2014; 17, 357-369. PMID: 24967065

23. Rouge N, Leroux JC, Cole ET, Doelker E, Buri P. Prevention of the sticking tendency of floating minitablets filled into hard gelatine capsules. Eur J Pharm Biopharm. 1997; 43:165-71.

https://doi.org/10.1016/S0939-6411(96)00003-3 